\title{
Educação Ambiental: Um diálogo entre a legislação e a prática dos professores de escolas públicas de Araripina - PE, 2013-2014
}

\author{
Maria Cristina Delmondes Nascimento ${ }^{1}$; Júlio César Cardozo Rolon ${ }^{2}$
}

\begin{abstract}
Resumo: Trata-se de um trabalho investigativo, onde almeja: Discutir como acontece o diálogo entre a legislação e a prática dos professores de duas escolas públicas do município da Araripina - Pernambuco no período de 2013 e 2014. A pesquisa apresenta uma abordagem de investigação quantitativa. O universo de pesquisa foram as escolas públicas Dionísio Bom de Oliveira e Moisés Bom de Oliveira, tendo como os sujeitos da pesquisa um universo de 45 docentes. Para alcançar os objetivos propostos os mesmos foram entrevistados segundo um roteiro estruturado baseado em um questionário, as respostas foram submetidas à analise temática de conteúdo. A pesquisa comprovou que o diálogo entre teoria e prática nas escolas investigadas necessita de maior efetividade para minimizar as dificuldades para implementação e estímulo a atividades e projetos de Educação Ambiental, que é trabalhada nos temas transversais, sendo ela essencial, principalmente quando é voltada para a formação de valores e que se trata de um processo de educação e reflexão permanente na construção de sujeitos cidadãos.
\end{abstract}

Palavras-chave: Educação Ambiental, legislação e prática de professores.

\section{Educación Ambiental: Un diálogo entre las leyes y prácticas de los maestros de las escuelas públicas en Araripina - PE, 2013-2014}

Resumen: Es un trabajo de investigación, que tiene como objetivos: Discutir cómo hace el diálogo entre la legislación y la práctica de la profesores de dos escuelas públicas del municipio de Araripina - Pernambuco entre 2013 y 2014. La investigación presenta un enfoque de la investigación cuantitativa. El universo de estudio fueron escuelas públicas Dionisio de Oliveira Bueno y Bueno Moisés de Oliveira que tienen como sujetos de investigación de un universo de 45 maestros. Para lograr las metas que fueron entrevistados de acuerdo a una entrevista estructurada sobre la base de un cuestionario, las respuestas fueron sometidas a análisis de contenido. La investigación demuestra que el diálogo entre la teoría y la práctica en las escuelas investigadas requiere más eficaz para reducir al mínimo las dificultades de aplicación y el fomento de actividades y proyectos de Educación Ambiental, que se hace a mano en los temas transversales, es esencial, sobre todo cuando se está frente a la formación de valores y que es un proceso de aprendizaje permanente y la reflexión en la construcción de sujetos ciudadanos.

Palabras clave: Educación ambiental, La legislación y la práctica de los docentes.

\footnotetext{
${ }^{1}$ Graduação em Ciências Biológicas pela Universidade Federal do Vale do São Francisco, graduação em Engenharia Agronomica pela Faculdade de Ciências Agrárias De Araripna (2010), graduação em Licenciatura Em Pedagogia pela Faculdade Evangélica do Piauí e mestrado em Ciências da Educação pela Universidade Hispano Guaraní (2016). Atualmente é professor do departamento pedagógico do Instituto Educacional Ruymar Gomes, professora da Escola Dionisio Bom De Oliveira. Autor Correspondente: Cristina_delmondes@hotmail.com;

${ }^{2}$ Universidade Hispano Guaraní.
} 
Id on Line Revista Multidisciplinar e de Psicoloqia

Id on Line Multidisciplinary Journal and Psycology

\section{Educação Ambiental no espaço escolar}

O âmbito escolar é um espaço privilegiado para o ensino da EA, é nele que se pretende, desde a infância, despertar no ser humano a consciência coletiva voltada para a preservação e o respeito ao meio ambiente. Contudo, essa articulação deve estar presente, de forma integrada, em todo processo educativo, sendo hoje pertinente que os currículos escolares busquem desenvolver práticas pedagógicas ambientalizadas.

A principal função do trabalho com o tema Meio Ambiente é contribuir para a formação de cidadãos conscientes, aptos para decidirem e atuarem na realidade socioambiental de um modo comprometido com a vida, com o bem-estar de cada um e da sociedade, local e global. Para isso é necessário que, mais do que informações e conceitos, a escola se proponha a trabalhar com atitudes, com formação de valores, com o ensino e a aprendizagem de habilidades. E esse é um grande desafio para a educação.

O papel da escola também envolve proporcionar um ambiente escolar saudável e coerente com aquilo que ela pretende que seus alunos aprendam, para que possa, de fato, contribuir para a formação de cidadãos conscientes de suas responsabilidades com o meio ambiente e capazes de atitudes de proteção e melhoria em relação a ele.

A importância do trabalho com a educação ambiental revela alguns critérios favoráveis, como: a importância dos conteúdos para uma visão integrada da realidade, especialmente sob o ponto de vista socioambiental; a capacidade de apreensão e necessidade de introdução de hábitos e atitudes; a possibilidade de desenvolvimento de procedimentos e valores básicos para o exercício pleno da cidadania.

As transformações são necessárias e a escola, acredita-se, deve exercer o seu papel, o que não significa eximir outras esferas da sociedade de cumpri-lo também. Comportamentos "ambientalmente corretos" são aprendidos na prática do dia-a-dia escolar. No entanto, há outros componentes que vêm se juntar à escola nessa tarefa.

Apresentar a EA aos alunos pelas instituições públicas ou privadas não é uma opção, é direito acobertado por lei, inclusive pela lei suprema (Constituição Federal), que no seu artigo 225, capítulo IV, referindo ao Meio Ambiente, afirma que o Poder Público é encarregado de "promover a educação ambiental em todos os níveis de ensino e a conscientização pública para a preservação do meio ambiente".

Porém é visível o despreparo dos profissionais da educação em colocar em prática o real objetivo da EA, entre os quais estão: "o incentivo à participação individual e coletiva, permanente e responsável, na preservação do equilíbrio do meio ambiente, entendendo-se a defesa da qualidade 
ambiental como um valor inseparável do exercício da cidadania" (Art. $5^{\circ}$, inciso IV) assim como o conhecimento da legislação que rege tal tema.

Para ensinar de maneira coerente é preciso conhecer a lei, caso contrário tal ação será efetuada de forma desarticulada.

Entende-se por educação ambiental na educação escolar a desenvolvida no âmbito dos currículos das instituições de ensino públicas e privadas, englobando: I - educação básica: a) educação infantil; b) ensino fundamental e c) ensino médio; II - educação superior; III - educação especial; IV educação profissional; V - educação de jovens e adultos.” ((Lei N ${ }^{\circ} 9.795$, de 27 de Abril de 1999.art. 9º ).

Para o cumprimento desse artigo é de suma importância que o espaço escolar esteja aberto ao desejo de realizar tal desenvolvimento, que haja um olhar voltado para realizações de ações eficazes.

Não é difícil perceber que a solução principal parte do campo educacional, exigindo que todos - governos, universidades, - andem de mão dadas, com objetivos comuns; que nos espaços escolares não seja focado simplesmente nas disciplinas obrigatórias (português, matemática, ciências, história, geografia e artes) - já que a EA não pode ser vista como disciplina especifica nos currículos de ensino, exceto nos cursos de pós-graduação, extensão e nas áreas voltadas aos aspectos metodológicos quando necessário, como ventila a Política Nacional de Educação Ambiental em seu artigo X e para completar os PCNs fazendo referência ao Meio Ambiente e Saúde no volume 9, página 49 expõe:

As áreas de Ciências Naturais, História e Geografia serão as principais parceiras para o desenvolvimento dos conteúdos aqui relacionados, pela própria natureza dos seus objetos de estudos. As áreas de Língua Portuguesa, Matemática, Educação Física e Arte ganham importância fundamental por constituírem instrumentos básicos para que o aluno possa conduzir o seu processo de construção do conhecimento sobre meio ambiente.

E sobre a transversalidade afirma que:

Os conteúdos de Meio Ambiente serão integrados ao currículo através da transversalidade, pois serão tratados nas diversas áreas do conhecimento, de modo a impregnar toda a prática educativa e, ao mesmo tempo, criar uma visão global e abrangente da questão ambiental.

A ação consciente de ensinar exige clareza com os objetivos educacionais e coerência com sua operacionalidade pedagógica, assim a escolha de se trabalhar com o tema EA vem acompanhada da necessidade de adquirir conhecimento e informação por parte dos docentes da escola para só então desenvolver um trabalha adequado junto aos alunos. 
Id on Line Revista Multidisciplinar e de Psicoloqia

Id on Line Multidisciplinary Journal and Psycology

Pela dimensão que é a questão ambiental, se faz necessário a busca incessante de informações sobre o tema por parte de todos envolvidos no processo ensino-aprendizagem. Isso não significa que a comunidade escolar deverá possuir todo o saber a respeito do tema, mas sim estar dispostos a prender sobre o assunto e "transmitir aos seus alunos a noção de que o processo de construção e de produção do conhecimento é constante" (PCN Meio Ambiente e Saúde, vol. 9, p. 47).

Podem-se estabelecer algumas orientações didáticas, a fim de auxiliar o trabalho da escola acerca do tema EA. Uma delas inclui uma revisão da prática pedagógica adotada (temas tratados, métodos/materiais utilizados, estratégias de abordagem, de mobilização, de envolvimento da escola e da comunidade, etc.) diante dos resultados obtidos (motivação geral, alcance dos objetivos, mudanças observadas nas pessoas e/ou nos ambientes, produtos obtidos, prazer no desenvolvimento das atividades e/ou na obtenção dos resultados, etc.).

Tendo em vista principalmente o reconhecimento dos pontos fortes e dos problemas e dificuldades encontradas, para dar sequência aos trabalhos revendo o que for necessário, ampliando, recomeçando, mudando, mantendo elementos, enfim, aprendendo com a experiência.

No artigo 156 da Lei Orgânica do Município de Araripina, encontra-se o seguinte enunciado: "os currículos escolares serão adaptados às peculiaridades do Município e a valorização de seu patrimônio histórico, artístico, cultural e ambiental.”. No $\S 2^{\circ}$ é escrito que no currículo de ensino constarão noções de ecologia e meio ambiente, com intuito de lutar pela preservação da fauna e flora locais. É de suma importância a transmissão dessas informações presentes em lei para os docentes, norteando-os a seguir uma trajetória condizente com suas práticas.

As escolas atuais, com o modelo de educação que encontramos em suas práticas, reproduzem e reforçam essa postura antropocêntrica. Neste sentido, Silva $(2007$, p. 32) explica que "a escola contribui para a reprodução da sociedade capitalista ao transmitir, através das matérias escolares, as crenças que nos fazem ver os arranjos sociais existentes como bons e desejáveis".

Desta forma, o currículo é visto sob uma O currículo, nas instituições de ensino, se apresenta como uma grade curricular que se refere a um organograma fixo e eficientemente compartimentado onde se encontram as caixinhas disciplinares contendo o quê, como e quando devemos nos deparar com o conhecimento elaborado na nossa vida escolar (CAVALCANTE, 2005, p. 120)

O currículo não é um elemento inocente e neutro de transmissão desinteressada do conhecimento social. O currículo está implicado em relações de poder, o currículo transmite visões sociais particulares e interessadas, o currículo produz identidades individuais e sociais particulares. 
A tradicional relevância que é dada à transmissão de conhecimento precisa ser substituída por um programa que parta de questionamentos como "que tipo de pessoa quero formar?". Se se deseja formar um indivíduo crítico, autônomo, com capacidade de tomar decisões fundamentadas contemplando as discussões relativas aos problemas socioambientais, o currículo deve ser construído nessa concepção. "Afinal, um currículo busca precisamente modificar as pessoas que vão "seguir" aquele currículo" (SILVA, 2007, p. $15)$.

A EA tem papel importante em auxiliar as pessoas a questionarem-se sobre os problemas ambientais e entender a relação entre as questões ambientais e as decisões político-econômicas.

A interdisciplinaridade aparece como uma forma de evitar a redução do complexo ao simples, de evitar uma compreensão equivocada da dinâmica das inter-relações dos componentes do mundo. É uma ruptura com os limites impostos pela racionalidade moderna. Para Gallo (2001, p. 19), "os professores começaram a se incomodar com o fato de os alunos não serem capazes de estabelecer as interconexões entre as diferentes disciplinas como eles gostariam que acontecesse". Portanto, a interdisciplinaridade deve ser concebida como possibilidade de nova organização do trabalho pedagógico.

Cascino (2007, p. 68) explica que as escolas entendem a interdisciplinaridade como um cruzamento de disciplinas que se "parecem" demonstrando "a precariedade da reflexão sobre esse conceito-chave para a reconstrução da ideia de educação". Carvalho (2000) define interdisciplinaridade como:

(...) uma maneira de organizar e produzir conhecimento, buscando integrar as diferentes dimensões dos fenômenos estudados. Com isso, pretende superar uma visão especializada e fragmentada do conhecimento em direção à compreensão da complexidade e da interdependência dos fenômenos da natureza e da vida. Por isso é que podemos também nos referir à interdisciplinaridade como uma postura, como nova atitude diante do ato de conhecer (CARVALHO, 2000, p. 09).

Elege-se um tema central para que as diferentes disciplinas realizem atividades a partir dele, e com isso, divulgam uma imagem de renovação e integração.

A EA pode contribuir com a mudança de postura pois, a crise ambiental alimenta essa discussão sobre uma nova forma de ver o mundo ao expor a insuficiência dos saberes disciplinares e reivindicar novas aproximações para que se compreenda a complexidade das inter-relações na base dos problemas ecológicos (CARVALHO, 2006, p. 123). 
Os problemas socioambientais exigem que transitemos entre os diversos saberes superando o tradicionalismo presente no ambiente escolar, propondo metodologias inovadoras e priorizando novas relações na organização do trabalho pedagógico.

Na opinião de Busquets (2000, p. 13), “Trabalhar a transversalidade no contexto escolar significa manter as disciplinas do currículo tradicional, mas os seus conteúdos devem ser impregnados com os temas transversais". Corroborando, Gallo (2001, p. 21) afirma que os temas transversais "devem passar a ser o eixo em torno do qual as disciplinas e as áreas se organizem, ressignificando as próprias disciplinas".

Freire (2005, p. 82), explica que "na prática problematizadora, vão os educandos desenvolvendo o seu poder de captação e de compreensão do mundo que lhes aparece, em suas relações com ele, não mais como uma realidade estática, mas como uma realidade em transformação, em processo". Para que a EA se efetive no ambiente escolar é necessário que professores e estudantes estabeleçam uma relação direta entre o conhecimento dos conteúdos "disciplinares" e os problemas vividos em sociedade e, principalmente, no ambiente em que vivem.

Porém, esta forma de trabalho depende de uma abordagem interdisciplinar que ainda não faz parte das práticas escolares. Tomazello (2001) explica que não há uma metodologia própria ou específica para o trabalho por projetos, mas ele tem como característica a interdisciplinaridade e por isso possibilita a utilização de todos os métodos didáticos preconizados nas diversas áreas disciplinares. A autora ainda cita algumas metodologias utilizadas com resultados positivos como: investigações, entrevistas, estudos de campo, visitas a museus e trilhas, elaboração de jogos didáticos e simulações entre outros.

$\mathrm{O}$ ensino sobre o meio ambiente deve contribuir principalmente para o exercício da cidadania, estimulando a ação transformadora além de buscar aprofundar os conhecimentos sobre as questões ambientais de melhores tecnologias, estimular a mudança de comportamento e a construção de novos valores éticos menos antropocêntricos (BERNA, 294, p. 18).

Segundo Morin (2006):

A educação deve favorecer a aptidão natural da mente em formular e resolver problemas essenciais e, de forma correlata, estimular o uso total da inteligência geral. Este uso total pede o livre exercício da curiosidade, a faculdade mais expandida e a mais viva durante a infância e adolescência, que com frequência a instrução extingue e que, ao contrário se trata de estimular ou, caso esteja adormecida de despertar (MORIN, 2006, p. 39).

De acordo com a exposição de Morin (2006) analisa-se que a Educação Ambiental apresentase como indispensável na evolução educacional da sociedade que está se adaptando à nova realidade 
Id on Line Revista Multidisciplinar e de Psicoloqia

Id on Line Multidisciplinary Journal and Psycology

mundial, que pede um comprometimento com o crescimento sustentável, sempre preservando os recursos naturais. Conforme Berna (2004, p. 30) "o educador ambiental deve procurar colocar os alunos em situações que sejam formadoras, como por exemplo, diante de uma agressão ambiental ou conservação ambiental, apresentando os meios de compreensão do meio ambiente".

Penteado (2007) afirma que os alunos, quando são sujeitos ativos e participativos na ação educativa, adotam como consequência uma postura que os faz se envolver, se empolgar e aprendem muito mais, do que quando são apenas leitores e ouvintes. Portanto, a Educação Ambiental trata a educação integrada à cidadania, à formação da consciência ecológica, saindo da sala de aula de forma transdisciplinar, desenvolvendo atitudes ambientalmente corretas.

No entanto, segundo Bruggër (1999), em muitas escolas no Brasil, as atividades que são relacionadas com a Educação Ambiental têm sido confundidas com algumas disciplinas ou apenas estão recebendo o caráter naturalista de preservação da natureza, realizando caminhadas através de trilhas ecológicas, realizando visitas a parques, ou a mananciais.

A sensibilização para os problemas ambientais vem ocorrendo, através de participação em campanhas preservacionistas, comemorações do dia do meio ambiente, plantando árvores etc.. Enfatiza a autora, que essa é uma abordagem insuficiente para desenvolver valores e atitudes ecológicos. Frente aos vários problemas ambientais, decorrentes das atividades praticadas pelo homem, torna-se necessário que o tema Meio Ambiente seja abordado de forma transdisciplinar e também no Ensino Fundamental.

As crianças, em contato com a natureza crescerão com mais conhecimentos e mais sensibilizados a respeito da forma como deverão tratá-la, evitando desde cedo os problemas de desrespeito ao meio ambiente. $\mathrm{E}$ isso pode diminuir o desequilíbrio entre a natureza e a sociedade em seu dia a dia.

\subsection{Tipo e método de pesquisa}

Trata-se de um estudo de campo de abordagem predominantemente quantitativa, por utilizar de análise estatística para a apresentação e análise dos resultados. O referencial teórico-metodológico que orientou o presente estudo foi o das representações sociais. Estas são entendidas como modalidades de um conhecimento prático, que são orientadas para a comunicação e compreensão de um dado contexto social, material e ideativo. Objetivamente são formas de conhecimento que tendem a se manifestarem como elementos cognitivos, conceitos, imagens, categorias ou teorias, mas que não se reduzem a eles.

As Representações Sociais pertencem a um campo transdisciplinar. Podem ser abordadas tanto pela Psicologia, pela Educação, Sociologia, Psicanálise, Antropologia ou Medicina. Objeto de estudo 
Id on Line Revista Multidisciplinar e de Psicoloqia

Id on Line Multidisciplinary Journal and Psycology

da Psicologia Social, as representações sociais também se assemelham a Epidemiologia quando pensada numa perspectiva das representações em determinada população (SPINK, 2002, 1993).

A palavra representação está associada aqui ao sentido de reprodução do pensamento e percepção dos sujeitos, abrindo caminho para o paradigma construtivista (SPINK, 2002, 1993). As representações sociais são definidas como formas de conhecimento prático e, inserem-se mais especificamente, entre as diversas correntes que estudam o conhecimento do senso comum. Os saberes enquanto saberes querem formalizados ou não, tendem a superar a clivagem entre a ciência e o senso comum.

Tal perspectiva amplia o olhar, admitindo este conhecimento também como legítimo e, motor das transformações sociais. A palavra "representação" também pode significar uma particular forma de interpretação. Nesta perspectiva, não se trata mais da natureza do conhecimento que esteja em pauta, mas sim, as suas implicações práticas. O conhecimento estudado através das representações sociais será sempre uma forma comprometida de interpretar a realidade (SPINK, 2002, 1993).

As representações sociais são estruturadas na interface de contextos sociais que são também históricos. Este imaginário social é o conjunto cumulativo das produções culturais que permeiam uma determinada sociedade, sob diversas formas, tais como: literatura, iconografia, canções, mitos e provérbios (SPINK, 2002, 1993).

Sob a perspectiva do referencial teórico-metodológico da teoria das representações sociais, duas escolas foram selecionadas mediante critérios prévios. A amostra teve como critério básico a capacidade de refletir, um conjunto de experiências sobre educação ambiental, que se pretendia demonstrar com a pesquisa (MINAYO, 2000). As escolas selecionadas foram: Escola Dionísio Bom de Oliveira e Escola Moisés Bom de Oliveira, Localizadas em Araripina - PE.

Considerando-se os critérios de seleção, os professores foram entrevistados, segundo um roteiro estruturado que incluiu um questionário (apêndice E), que incluiu os seguintes aspectos:

A) Identificação de professores quanto ao gênero, idade, escolaridade, tempo de atuação na área;

B) Questões conceituais sobre a educação ambiental. A saber: educação ambiental e desenvolvimento sustentável, bem como sua importância;

C) Questões relacionadas as representações sociais dos professores sobre a temática; bem como suas percepções sobre contribuições obtidas com a implantação da disciplinas, dificuldades na manutenção das aulas e mudanças observadas nos alunos.

Em ambas as escolas os questionários foram individuais e respondidos pelos próprios sujeitos. As respostas foram submetidas à análise temática de conteúdo. Levando-se em conta os critérios apontados por Bardin (2001). Isto é, procurar conhecer o que encontra-se por trás das palavras; Tentar 
Id on Line Revista Multidisciplinar e de Psicoloqia

Id on Line Multidisciplinary Journal and Psycology

encontrar o sentido da comunicação; Cuidar para desviar o olhar para outras significações, outras mensagens através ou de maneira próxima a primeira.

Este projeto foi submetido ao Comitê de Ética em Pesquisa com Seres Humanos através da Plataforma Brasil. Todos os participantes participaram de forma voluntária e foram devidamente esclarecidos do propósito do estudo, como recomendado pela Resolução 196/96 sobre experimentação com seres humanos no Brasil.

\section{Desenho da investigação}

Pesquisa não experimental, do tipo transversal, por que visa caracterizar um determinado aspecto de uma população num momento dado do tempo, neste caso, de 2013 a 2014. Os dados foram coletados num curto período de tempo.

\section{Universos de pesquisa}

A pesquisa foi desenvolvida em duas escolas no município de Araripina, a saber: Escola Dionísio Bom de Oliveira e Escola Moisés Bom de Oliveira, localizadas no interior do estado de Pernambuco. Para uma melhor visualização do espaço geográfico pernambucano observe-se a figura abaixo.

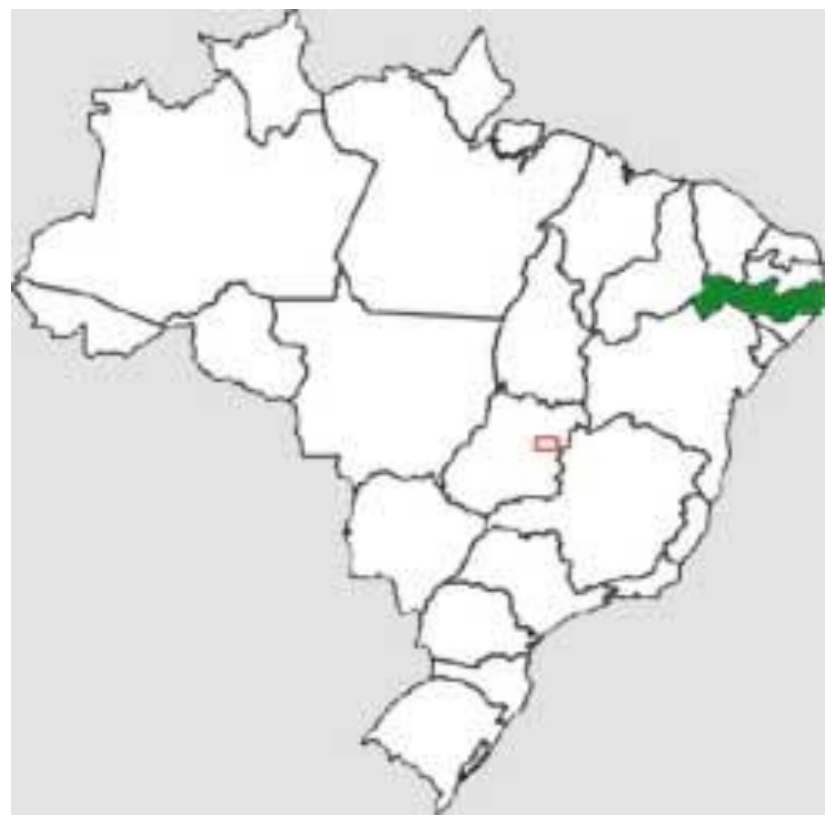

Figura 1 - Mapa - Localização do Estado de Pernambuco no espaço geográfico brasileiro 
Pernambuco é um dos estados que forma a região Nordeste. Pertence ao conjunto dos 26 estados brasileiros e, encontra-se divido em 178 municípios, dentre os quais, Araripina, conforme a figura 2, a seguir:

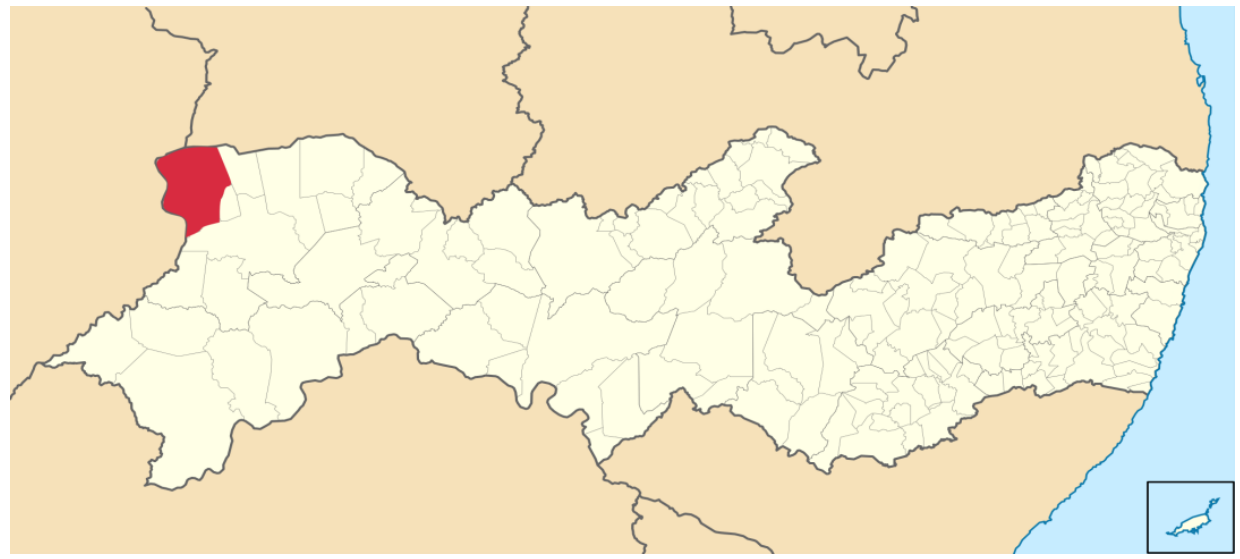

Figura 2 - Mapa - Localização do Município de Araripina no estado pernambucano

Araripina é conhecido como a cidade do gesso, pois é responsável por $95 \%$ do gesso consumido no Brasil (Araripina, Wikipédia), possuindo o quinto maior PIB do sertão pernambucano, por outro lado a produção do gesso provoca: poluição do ar; desmatamento; degradação do solo; erosão, etc. apresentando assim a urgência de políticas educativas e públicas que trabalhem de mãos dadas para preservar e evitar danos provocados pela produção e uso do gesso a nível local e comumente a isso global.

Atualmente o município dispõe das seguintes distribuições de escolas públicas e privadas.

\begin{tabular}{|l|c|c|}
\hline \multicolumn{1}{|c|}{ Localidade (Setor) } & $\mathrm{N}^{\circ}$ de Escolas Públicas & $\mathrm{N}^{\circ}$ de Escolas Privadas \\
\hline $\mathrm{A}$ & 18 & 07 \\
\hline $\mathrm{B}$ & 16 & - \\
\hline $\mathrm{C}$ & 25 & - \\
\hline $\mathrm{D}$ & 12 & - \\
\hline MORAIS & 17 & 01 \\
\hline LAGOA DO BARRO & 10 & 01 \\
\hline NASCENTE & 09 & - \\
\hline GERGILIN & 06 & 09 \\
\hline BOM JARDIM & 10 & \\
\hline TOTAL & 123 & \multicolumn{2}{|c|}{132} \\
\hline SOMATÓRIO & \multicolumn{2}{|c|}{} \\
\hline
\end{tabular}

Quadro 1 - Escolas públicas e privadas do município de Araripina

Fonte: Secretaria Municipal de Araripina. 03/09/2013 
Id on Line Revista Multidisciplinar e de Psicoloqia

Id on Line Multidisciplinary Journal and Psycology

Foram selecionadas como o lócus da pesquisa, as escolas: DIONÍSIO BOM DE OLIVEIRA e MOISÉS BOM DE OLIVEIRA, pois são as duas únicas escolas localizadas no distrito do Moraes, Araripina - PE.

A Escola Dionísio Bom de Oliveira (EDBO) faz parte das 123 escolas públicas municipais de Araripina- PE, comporta em média uma quantidade de 460 alunos divididos nas turmas de Educação Infantil, Ensino Fundamental ( $1^{\circ}$ ano ao $6^{\circ}$ ano). A instituição executa três programas Governamentais entre eles o Programa Mais Educação onde funciona no contra turno ofertando a Educação Ambiental como macro Campo dentro do qual é ensinado aos alunos Agenda 21 na escola, Educação para a Sustentabilidade e Horta Escolar e/ou Comunitária; Atleta na Escola, mesmo com todos esses instrumentos é perceptível que as ações relacionado a Educação Ambiental são desenvolvidas timidamente, quase ausente, pois observando informalmente nota-se que esses instrumentos são repassados unicamente de forma teórica sem efeito prático.

O quadro abaixo apresenta a distribuição de professores com a respectiva função e grau de escolaridade da Escola Dionísio Bom de Oliveira.

\begin{tabular}{|c|c|c|c|}
\hline \multicolumn{4}{|c|}{ QUADRO DE PROFESSORES } \\
\hline $\mathrm{N}^{\circ}$ & Nome & Função & Grau de Escolaridade \\
\hline 01 & Francisca Sibelúcia Araújo & Infantil I "A" & \begin{tabular}{|l} 
Lic. em Pedagogia \\
\end{tabular} \\
\hline 02 & $\begin{array}{l}\text { Maria Silmária Rodrigues } \\
\text { Silva }\end{array}$ & Infantil I “A” & Normal Médio \\
\hline 03 & Francimária Sousa S. Silvana & Infantil II "A" & Esp. em Geografia/Educ. Especial \\
\hline 04 & Tatiane Lopes Soares da Silva & \begin{tabular}{|l|} 
Infantil II "B" \\
\end{tabular} & Esp. Em Gestão Escolar \\
\hline 05 & $\begin{array}{l}\text { Maria Betânia Nascimento } \\
\text { Bihum }\end{array}$ & Professora $1^{\circ}$ Ano "A" & Esp. em Psicopedagogia \\
\hline 06 & $\begin{array}{l}\text { Celma Maria Lima Rodrigues } \\
\text { Oliveira }\end{array}$ & Professora $1^{\circ}$ Ano "B" & Normal Médio (Magistério) \\
\hline 07 & Elzani de Sousa Melo Lima & Professora $2^{\circ}$ Ano "A" & Lic. em Pedagogia \\
\hline 08 & Juçara Gomes Baldoíno & Professora $2^{\circ}$ Ano "B" & Lic. em Letras \\
\hline 09 & Ana Cristina Pereira Silva & Professora $3^{\circ}$ Ano "A" & Lic. em Pedagogia \\
\hline 10 & $\begin{array}{l}\text { Ednilda Maria de Amorim } \\
\text { Silva }\end{array}$ & Professora $3^{\circ}$ Ano "B" & Esp. em Psicopedagogia \\
\hline 11 & Solange Maria de Souza & Professora $3^{\circ}$ Ano "C" & Pós-graduação em Matemática \\
\hline 12 & $\begin{array}{l}\text { Francisca Aparecida G. } \\
\text { Delmondes }\end{array}$ & Professora $4^{\circ}$ Ano "A" & Especialização em Geografia \\
\hline 13 & Marileide Pereira Soares & Professora $4^{\circ}$ Ano "B" & Lic. em Pedagogia \\
\hline 14 & $\begin{array}{l}\text { Maria Rosária Nascimento } \\
\text { Leite }\end{array}$ & Professora $4^{\circ}$ Ano "B" & Normal Médio (Magistério) \\
\hline 15 & Edjonas Silvana Lopes & $\begin{array}{l}\text { Professor } 6^{\circ} \text { Ano, } 5^{\circ} \text { Ano } \\
\text { "A, B" }\end{array}$ & Esp. em Biologia \\
\hline 17 & Marineide Alves dos Santos & $\begin{array}{l}\text { Professora } 6^{\circ} \text { Ano, } 5^{\circ} \text { Ano } \\
\text { "A, B" }\end{array}$ & $\begin{array}{l}\text { Esp. em gestão Escolar com ênfase em } \\
\text { Pedagogia }\end{array}$ \\
\hline 18 & Solange Maria de Souza & $\begin{array}{l}\text { Professora } 6^{\circ} \text { Ano, } 5^{\circ} \text { Ano } \\
\text { "A, B" }\end{array}$ & Pós-graduação em Matemática \\
\hline 19 & $\begin{array}{l}\text { Antonia Andrade do } \\
\text { Nascimento }\end{array}$ & Professora $5^{\circ}$ Ano "C" & Esp. em Psicopedagogia \\
\hline
\end{tabular}


Id on Line Revista Multidisciplinar e de Psicoloqia

Id on Line Multidisciplinary Journal and Psycology

\begin{tabular}{|l|l|l|l|}
\hline 20 & Maria Josilda Pereira Mota & Professora 5 $5^{\mathbf{A}}$ Ano "C" & Esp. em História \\
\hline 21 & Alexcilda Lima B. Sousa & Aux. de Sala & Licenciatura em Pedagogia \\
\hline 22 & $\begin{array}{l}\text { Francisca Magnaete C. do } \\
\text { Nascimento }\end{array}$ & Aux. de Sala & Licenciatura em Geografia \\
\hline 23 & Poliana Neri L. Delmondes & Aux. de Sala & Lic. Em pedagogia \\
\hline
\end{tabular}

Quadro 2 - Distribuição de professores: função e grau de escolaridade

Fonte: Projeto político pedagógico da EDBO, 2013

A Escola Moisés Bom de Oliveira (EMBO) apresenta como entidade mantenedora a Secretaria Estadual de Educação do Estado de Pernambuco, oferta os níveis de Ensino Fundamental nos anos finais e Ensino Médio, a modalidade de Educação de Jovens e Adultos (EJA) e Programa Travessia Fundamental e médio distribuídos nos três turnos manhã, tarde e noite, conforme descrição abaixo.

\begin{tabular}{|c|c|c|c|c|c|}
\hline \multicolumn{2}{|c|}{ Manhã } & \multicolumn{2}{|c|}{ Tarde } & \multicolumn{2}{|c|}{ Noite } \\
\hline $7 \mathrm{~h} 30 \mathrm{~m}$ & as $12 \mathrm{~h} 00$ & $13 \mathrm{~h} 0$ & $17 \mathrm{~h} 30$ & $18 \mathrm{~h} 40$ à & \\
\hline Turmas & $\begin{array}{l}\mathrm{N}^{\mathrm{o}} \text { de } \\
\text { estudantes }\end{array}$ & Turmas & $\begin{array}{l}\mathrm{N}^{\mathrm{o}} \text { de } \\
\text { estudantes }\end{array}$ & Turmas & $\begin{array}{l}\mathrm{N}^{\mathrm{o}} \text { de } \\
\text { estudantes }\end{array}$ \\
\hline $6^{\circ}$ Ano $\mathrm{A}$ & 40 & $6^{\circ}$ Ano B & 34 & IV Fase U & 22 \\
\hline $7^{\circ}$ Ano $\mathrm{A}$ & 37 & $6^{\circ}$ Ano $\mathrm{C}$ & 30 & $2^{\circ}$ Ano B & 27 \\
\hline $7^{\circ}$ Ano B & 38 & $7^{\circ}$ Ano C & 37 & $3^{\circ}$ Ano U & 23 \\
\hline $8^{\circ}$ Ano $\mathrm{A}$ & 28 & $8^{\circ}$ Ano B & 37 & Travessia Fund U & \\
\hline $9^{\circ}$ Ano A & 30 & $9^{\circ}$ Ano B & 26 & Travessia Médio A & \\
\hline $2^{\circ}$ Ano $\mathrm{A}$ & 22 & $1^{\circ}$ Ano $U$ & 38 & & \\
\hline
\end{tabular}

Quadro 3 - Horário de funcionamento da Escola Moisés Bom de Oliveira

Fonte: Projeto político pedagógico da EMBO, 2013

A EMBO assim como a EDBO desfruta do PROGRAMA MAIS EDUCAÇÃO auxiliando em ações ambientais.

A população corresponde aos 45 professores das duas escolas. A Escola Dionísio Bom de Oliveira possui em seu quadro de funcionário docente uma característica diferenciada das demais, na qual todos os docentes são efetivos. Atualmente conta com 23 professores (2013), todos na área educacional. A Escola Moisés Bom de Oliveira dispõe de 22 docentes. Todos os professores (45) participaram da pesquisa. 
Id on Line Revista Multidisciplinar e de Psicoloqia

Id on Line Multidisciplinary Journal and Psycology

\section{Técnicas e instrumentos de coleta de dados}

O instrumento da pesquisa constou de um questionário, contendo informações com a finalidade de caracterizar os participantes do estudo, a exemplo de idade, sexo e escolaridade. Outra questão voltou-se para as Representações Sociais de Educação Ambiental.

Os dados foram analisados através do pacote estatístico SPSSWIN-18. Aqui se confirma a abordagem quantitativa ao tema. No instrumento, constaram ainda perguntas sobre a prática dos educadores no tocante a temática de educação ambiental, dificuldades encontradas no desenvolvimento de atividades nesta área do conhecimento e suas percepções sobre possíveis mudanças observadas nos discentes, como consequência das reflexões propostas pela educação ambiental.

\section{Procedimentos da análise de dados}

Os dados foram analisados através do pacote estatístico SPSSWIN-18. Foram procedidas as análises descritivas, procurando-se conhecer o perfil dos participantes, considerando as variáveis implicadas como sexo, idade, escolaridade, tempo de atuação como docente, se gosta da profissão, dentre outras.

A investigação apresenta-se dados onde foram analisados e interpretados de maneira descritiva e analisados seus conteúdos. Os mesmos foram categorizados segundo Bardin (2001). Estes envolveram as questões abertas, a exemplo de: Na sua percepção, o que representa Educação Ambiental?; Quais as dificuldades encontradas por você para ministrar aulas de educação ambiental (...); Na sua concepção, quais as mudanças que tem observado nos alunos, como consequência da

\section{Educação Ambiental.}

Para o propósito da presente pesquisa acreditou-se conveniente a formulação tanto de questões abertas quanto de questões fechadas, por conta da natureza das variáveis a serem estudadas, porém a abordagem ficou concentrada exclusivamente na quantitativa apesar de Creswell (2010) considera as abordagens qualitativa e quantitativa relativamente fáceis de implementar, descrever e relatar de forma direta.

A análise de dados na pesquisa de métodos mistos ocorre tanto na abordagem quantitativa - análise numérica descritiva e inferência, quanto na qualitativa - descrição e análise temática de texto ou imagem e frequentemente entre as duas abordagens (CRESWELL, 2010, p. 257). 
Id on Line Revista Multidisciplinar e de Psicoloqia

Id on Line Multidisciplinary Journal and Psycology

A Análise de conteúdo é explorada nas entrevistas à partir dos questionários previamente construídos para essa finalidade. Busca-se o sentido mais explicativo dos resultados da pesquisa, interpretando através dos índices, dos percentuais obtidos, da mediação e tabulação dos dados, para serem confrontados com os depoimentos.

O Projeto foi encaminhado a Plataforma Brasil, para autorização do trabalho de campo. Os sujeitos foram devidamente esclarecidos do propósito do estudo, de acordo com a Resolução 466/12 do Conselho Nacional de Saúde (Brasil), que trata das diretrizes de e normas regulamentadoras de pesquisas envolvendo seres humanos. Os dados irão permanecer sob a guarda do pesquisador, sendo garantido o seu sigilo e a confiabilidade das informações. Em anexo o Termo de Consentimento Livre e Esclarecido Individual e Institucional.

\section{Resultados e discussões}

Discutir como acontece o diálogo entre a legislação e a prática dos professores sobre a Educação Ambiental em escolas públicas de Araripina - Pernambuco no período compreendido entre 2013-2014 foi o propósito do presente estudo. As escolas envolvidas na pesquisa foram: Dionísio Bom de Oliveira e Moisés Bom de Oliveira. A tabela 1 mostra a quantidade de professores envolvidos nesta pesquisa, por escola.

\begin{tabular}{lcc}
\hline Número de professores por Escola & Frequência & Percentual (\%) \\
\hline Dionísio Bom de Oliveira & 23 & 51,0 \\
\hline Moisés Bom de Oliveira & 22 & 49,0 \\
\hline Total & $\mathbf{4 5}$ & $\mathbf{1 0 0 , 0}$ \\
\hline
\end{tabular}

Tabela 1 - Distribuição do Número de Professores por Escola

Fizeram parte deste estudo 45 professores. Todos os questionários foram considerados válidos. Observou-se uma distribuição equacionada por escola participante do estudo.

\begin{tabular}{lcc}
\hline Sexo & Frequência & Percentual (\%) \\
\hline Masculino & 15 & 33,3 \\
\hline Feminino & 28 & 62,2 \\
\hline Não Responderam esta questão & 02 & 4,5 \\
\hline Total & $\mathbf{4 5}$ & $\mathbf{1 0 0 , 0}$ \\
\hline
\end{tabular}

Tabela 2 - Gênero dos sujeitos da pesquisa 
Id on Line Revista Multidisciplinar e de Psicoloqia

Id on Line Multidisciplinary Journal and Psycology

Quanto ao gênero, a amostra é de maioria de educadores do sexo feminino, em número de 28 $(62,2 \%)$, sendo 15 do sexo masculino (33,3\%). Dois dos professores não responderam a esta questão $(4,5 \%)$. Com relação às idades, a amostra se comportou conforme a tabela 3.

\begin{tabular}{lcc}
\hline Faixa de Idades & Frequência & Percentual (\%) \\
\hline De 21 a 30 anos & 14 & 31,1 \\
\hline De 31 a 40 anos & 19 & 42,2 \\
\hline Acima de 40 anos & 12 & 26,7 \\
\hline Total & $\mathbf{4 5}$ & $\mathbf{1 0 0 , 0}$ \\
\hline
\end{tabular}

Tabela 3 - Distribuição das idades, por classe, dos sujeitos da pesquisa

Suas idades, por classe, tiveram a seguinte distribuição: 14 professores com idades entre 21 a 30 anos (31,1\%); 19 professores com idades entre 31 a 40 anos $(42,2 \%)$ e 12 professores com mais de 40 anos de idade $(26,7 \%)$.

Acredita-se ser importante a visualização gráfica da distribuição das idades. A mesma encontra-se disposta no gráfico 1 .

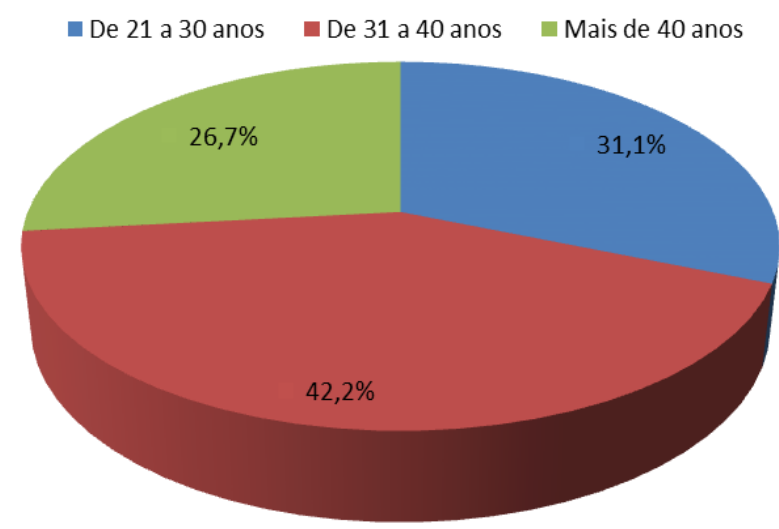

Gráfico 1 - Distribuição das Idades dos participantes por classes

O Gráfico 1 mostra que há professores relativamente jovens, na faixa de 21 a 30 anos, representando $31,1 \%$ da amostra. Os outros professores, mais maduros totalizam juntos $68,9 \%$ da amostra, com mais de 30 anos de idade.

Acreditou-se importante observar a Escolaridade dos sujeitos, dispostas na tabela 4, na sequência. 
Id on Line Revista Multidisciplinar e de Psicoloqia

Id on Line Multidisciplinary Journal and Psycology

\begin{tabular}{lcc}
\hline Escolaridade & Frequência & Percentual (\%) \\
\hline Ensino Médio Completo & 02 & 4,4 \\
\hline Superior incompleto & 03 & 6,7 \\
\hline Superior Completo & 03 & 6,7 \\
\hline Especialização & 35 & 77,8 \\
\hline Não responderam & 02 & 4,4 \\
\hline Total & $\mathbf{4 5}$ & $\mathbf{1 0 0 , 0}$ \\
\hline
\end{tabular}

Tabela 4 - Distribuição da Escolaridade dos sujeitos da pesquisa

Com relação à escolaridade, a amostra se comportou da seguinte maneira: 2 dos professores possuía apenas o Ensino Médio (4,4\%); 3 estavam cursando o nível superior (6,7\%); 3 já possuía o curso superior completo $(6,7 \%)$ e 35 já havia concluído curso de especialização $(77,8 \%)$. Apenas 2 professores não responderam a esta questão $(4,4 \%)$.

A formação de professores no Brasil ainda é considerada insatisfatória, quando se trata de conhecimentos mais específicos. Há algumas lacunas, por exemplo, quando se trata da Educação Ambiental, pois há uma priorização nos conhecimentos pedagógicos para uma formação teórica, mais do que a prática (CUNHA; KRASILCHIK, 2000).

Neste sentido, pode-se perceber que, a maior parte dos educadores no Ensino Fundamental e Médio em escolas públicas brasileiras, são educadores generalistas. Mesmo no caso da presente pesquisa, os professores "especialistas", nem sempre possuem uma formação para trabalhar determinados temas transversais, como é o caso da Educação Ambiental, em que se é cobrado que atuem.

Autores como Meglhioratti, Bortolozzi e Caldeira (2005), como também Bulos e Jesus (2006) orientam para um olhar que realce as falhas na formação desses conhecimentos específicos na formação do professor generalista, principalmente para as séries iniciais na Educação Básica. Nestes casos, os autores reforçam a ocorrência de sérios problemas conceituais, em conteúdos da disciplina de Ciências, por exemplo. Gatti e Nunes (2009), e Monfredini (2009) atribuem à formação deficiente dos cursos de pedagogia, que não possuem uma carga didática mais expressiva para como trabalhar com esses conteúdos mais específicos.

É possível que, a formação continuada, seja uma maneira de suprir tais deficiências na formação. Nesta linha de pensamento, Gabini e Diniz (2009) apontam resultados de pesquisas que reconhecem a formação continuada como importante estratégia, no sentido de atender às demandas mais específicas de cada escola. Outra justificativa para a educação continuada é a realidade da rapidez das mudanças nos tempos atuais, acelerados pelas descobertas científicas e pelas novas 
Id on Line Revista Multidisciplinar e de Psicoloqia

Id on Line Multidisciplinary Journal and Psycology

tecnologias, que fazem com que o conhecimento do professor, fique rapidamente obsoleto (LIMA, VASCONCELOS, 2008).

Abaixo, os resultados sobre o do tempo de docência dos entrevsitados.

\begin{tabular}{lcc}
\hline Tempo de docência & Freqüência & Percentual (\%) \\
\hline Menos de 1 ano & 1 & 2,2 \\
\hline De 1 a 5 anos & 12 & 26,7 \\
\hline De 6 a 10 anos & 12 & 26,7 \\
\hline Mais de 10 anos & 19 & 42,2 \\
\hline Não Respondeu & 1 & 2,2 \\
\hline Total & $\mathbf{4 5}$ & $\mathbf{1 0 0 , 0}$ \\
\hline
\end{tabular}

Tabela 5 - Distribuição do Tempo de docência dos sujeitos da pesquisa

Nota-se, pois, um bom percentual de professores mais experientes, já que 26,7\% da amostra tem entre 6 e 10 anos de magistério e, 42,2\% da amostra possui mais de 10 anos de magistério. Tal situação é importante para uma educação com reflexões mais maduras em relação às questões ambientais. A experiência profissional, certamente tende a conseguir melhores resultados.

Sobre essa questão, Arroyo (2000), nos informa que não são somente conhecimentos que são ensinados na escola, mas também, habilidades, atitudes e valores humanos. Estes quando postos em ação, produzem uma mudança mais efetiva no comportamento humano. Portanto, a maturidade dos educadores em lidar com temáticas voltadas para a educação ambiental pode ser vista como uma estratégia de mobilização a reflexões políticas sobre uma constante necessidade de capacitação profissional, nesta dimensão.

Para saber se há integração dos alunos em uma consciência coletiva faz-se necessário saber quais as estratégias utilizadas pelos sujeitos para desenvolverem atividades sobre as questões ambientais. As respostas foram as seguintes.

\begin{tabular}{lcc}
\hline $\begin{array}{l}\text { Estratégias utilizadas para trabalhar as } \\
\text { questões ambientais }\end{array}$ & Frequência & Percentual (\%) \\
\hline Músicas & 29 & 15,7 \\
\hline Desenhos & 26 & 14,0 \\
\hline Debates & 26 & 14,0 \\
\hline Vídeos & 25 & 13,4 \\
\hline Brincadeiras & 20 & 10,7 \\
\hline Passeios & 14 & 7,5 \\
\hline Palestras & 13 & 7,0 \\
\hline
\end{tabular}


Id on Line Revista Multidisciplinar e de Psicoloqia

Id on Line Multidisciplinary Journal and Psycology

\begin{tabular}{lcc}
\hline Teatro & 09 & 4,8 \\
\hline Painéis educativos & 09 & 4,8 \\
\hline Coleta de separação do lixo & 07 & 3,8 \\
\hline Cartilhas & 02 & 1,1 \\
\hline Outro & 06 & 3,2 \\
\hline $\begin{array}{l}\text { Nenhuma. Não discute questões ambientais em } \\
\text { sala de aula }\end{array}$ & - & - \\
\hline Total & $\mathbf{1 8 6}$ & $\mathbf{1 0 0 , 0}$ \\
\hline
\end{tabular}

Tabela 6 - Estratégias para trabalhar a EA

Quanto às estratégias utilizadas pelos professores da amostra, para trabalharem com as questões ambientais em sala de aula, observou-se que a mais utilizada foi a música $(15,7 \%)$, seguida do debate e do desenho (14\% e 14,0\% respectivamente); O vídeo foi referido por 13,4\% dos sujeitos e as brincadeiras por $10,7 \%$. Os passeios $(7,5 \%)$ e as palestras $(7,0 \%)$. Menos utilizadas como estratégia foram citadas o Teatro e os painéis educativos com $4,8 \%$ cada, a separação do lixo $(3,8 \%)$ e as cartilhas $(1,1 \%)$. Outras estratégias representaram 3,2\%.

Com relação às estratégias para implementação e desenvolvimento de projetos nas escolas, Jacobi (2005) orienta sobre alguns princípios na construção de novos procedimentos de ensino, que sejam capazes de integrar diferentes recursos nas atividades didático-pedagógicas que objetivam a educação ambiental, bem como a elaboração de propostas ou ações que visem a melhoria da qualidade de vida dos envolvidos ou da comunidade.

A saber: a) considerar as ideias, os interesses e necessidades dos envolvidos; b) buscar favorecer o desenvolvimento de uma formação continuada na temática; c) permitir uma reflexão individual e coletiva dos problemas e das dificuldades de aprendizagem cotidianas; d) facilitar a implementação de atitudes positivas para as novas práticas ambientais; e) propor uma transformação das dificuldades em desafios, levando-se em consideração os objetivos propostos no projeto de educação ambiental da escola; e, f) estimular a elaboração de projetos de educação ambiental, tanto pelos professores quanto pelos alunos.

Tais princípios pressupõem que a formação do docente não pode estar dissociada de uma transformação dos procedimentos didático-pedagógicos e de uma postura da escola.

Ainda segundo o autor, os projetos escolares desenvolvidos, devem procurar identificar e compreender a problemática socioambiental local, levantada por professores e alunos, assim como propor novas soluções para as mesmas, visando uma melhoria das condições sociais e ambientais na comunidade. Nesse sentido, contribuirão efetivamente para um processo de construção de uma consciência ambiental em professores e alunos, importantes no exercício da cidadania, e na formação 
Id on Line Revista Multidisciplinar e de Psicoloqia

Id on Line Multidisciplinary Journal and Psycology

de cidadãos mais críticos e participativos, que certamente atuarão como agentes modificadores de sua própria realidade.

Sobre as principais dificuldades na implementação da Educação Ambiental estas dispostas na tabela 7.

\begin{tabular}{lcc}
\hline Dificuldades & Frequência & Percentual (\%) \\
\hline Apoio e recursos & 19 & 42,2 \\
\hline Disposição e Conscientização & 10 & 22,2 \\
\hline Espaço & 06 & 13,3 \\
\hline Tempo & 04 & 8,9 \\
\hline Falta de material didático atualizado & 03 & 6,7 \\
\hline Não respondeu & 03 & 6.7 \\
\hline Total & $\mathbf{4 5}$ & $\mathbf{1 0 0 , 0}$ \\
\hline
\end{tabular}

Tabela 7 - Dificuldades na implementação da EA

As dificuldades na implementação de Atividades de Educação Ambiental foram assim descritas: 19 professores citaram apoio e recursos (42,2\%); 10 citaram disposição e conscientização por parte dos próprios educadores $(22,2 \%), 6$ citaram a questão do espaço para implementação das atividades $(13,3 \%) ; 4$ citaram o tempo como impedimento $(8,9 \%)$; 3 citaram a falta de material didático atualizado $(6,7 \%)$ e outros 3 não responderam $(6,7 \%)$.

O desafio não parece ser somente formular uma educação ambiental crítica e inovadora, mas uma espécie de ato político que seja voltado para a transformação social. Para Sorrentino (1998), há que se resgatar o desenvolvimento de valores e comportamentos (respeito, confiança, responsabilidade, honestidade, compromisso, solidariedade e iniciativa), além do estímulo a uma visão global e crítica sobre as questões ambientais. Somente com políticas públicas que levem em conta a importância de se destinar recursos materiais, físicos e humanos voltados para uma educação cidadã, é que podem promover um enfoque interdisciplinar que resgate e construa saberes nesta linha temática.

Observe-se que, quando nos referimos à educação ambiental, insinuamos um contexto mais amplo: qual seja o da educação para a cidadania, como um elemento determinante na consolidação de sujeitos efetivamente cidadãos. Ainda parece representar um desafio, o fortalecimento da cidadania para toda a população. Isto é, todos como portadora de direitos e deveres, capazes de se converter em atores corresponsáveis na defesa da qualidade de vida comum.

Portanto, o eixo principal de atuação da educação ambiental deve, acima de tudo, difundir a solidariedade, o respeito às diferenças e, a igualdade, através de práticas democráticas de atuação, que sejam interativas e dialógicas (JACOBI, 1997). Trata-se de uma abordagem multirreferencial, 
Id on Line Revista Multidisciplinar e de Psicoloqia

Id on Line Multidisciplinary Journal and Psycology

atravessada por diversos campos de conhecimento (LEFF, 2001) e que, reflete um conceito heterogêneo, onde os campos do saber e os conceitos se complementam (TRISTÃO, 2002).

Os desafios aos professores se mostraram mais no campo prático. Mas é preciso se levar em conta que, o contexto no qual se configuram as questões ambientais, tende a ser marcado pelo conflito de interesses, bem como de uma polarização entre as visões de mundo. Essas últimas decorrentes dos novos paradigmas do desenvolvimento e da globalização.

Assim, o desafio que está posto parece ser, não só se reconhecer, mas estimular práticas que reforcem e legitimem a autonomia dos atores sociais, numa perspectiva de cooperação. Isso representa a possibilidade de se mudar às práticas prevalecentes, rompendo-se com as lógicas da tutela e da regulação impostas, definindo-se novas relações baseadas na negociação e na gestão conjunta de programas e atividades alinhadas com uma política ambiental mais coerente com os anseios sociais.

A Educação Ambiental tem papel preponderante e relevante "tanto em relação às propostas de gestão educacional e do meio ambiente, quanto em políticas públicas e conhecimentos inerentes à temática, na releitura, no repensar das atitudes de ordem e valores individuais e coletivas". Precisa-se sair do campo da informação para a sensibilização em todos os níveis. E o que propõe (DIAS, 2003, p. 126) "Os processos de sensibilização tem o potencial de preparar pessoas para mudanças"

A integração entre os alunos acontece principalmente no ambiente escolar por isso faz-se necessário saber se a escola possui área arborizada no âmbito escolar para as atividades sobre educação ambiental e as respostas estão na tabela 8.

\begin{tabular}{lcc}
\hline A escola possui área arborizada? & Frequência & Percentual (\%) \\
\hline Sim & 35 & 77,8 \\
\hline Não & 10 & 22,2 \\
\hline Total & $\mathbf{4 5}$ & $\mathbf{1 0 0 , 0}$ \\
\hline
\end{tabular}

Tabela 8 - Arborização da escola

Quanto aos incentivos no desenvolvimento das atividades ambientais com os alunos, os sujeitos foram indagados sobre se desenvolviam algum projeto de Educação Ambiental na escola em que atuavam. As respostas estão na tabela abaixo.

\begin{tabular}{lcc}
\hline Desenvolve Projeto Ambiental na Escola? & Frequência & Percentual (\%) \\
\hline Sim & 32 & 71,1 \\
\hline Não & 12 & 26,7 \\
\hline Não respondeu & 01 & 2,2 \\
\hline Total & $\mathbf{4 5}$ & $\mathbf{1 0 0 , 0}$ \\
\hline
\end{tabular}

Tabela 9 - Projetos Ambientais 
Neste caso, observou-se que 77,8\% da amostra desenvolve algum tipo de Projeto ambiental na escola onde atuam e, 22,2\% ainda não o fazem.

Consultados se foram incentivados a desenvolver atividades ambientais com seus alunos, 32 responderam que $\operatorname{sim}(71,1 \%) ; 12$ responderam que não $(97,8 \%)$ e, 1 não respondeu a esta questão $(2,2 \%)$

Sobre a existência conteúdos relacionados à Educação Ambiental em livros didáticos, dos 45 sujeitos entrevistados sobre a utilização do o livro didático 36 docentes afirmam que os mesmos apresentam conteúdos sobre a temática Educação Ambiental (80\%), porém relatam que são assuntos superficiais, os outros 9 docentes dizem que os livros que utilizam não abordam conteúdos relacionados com a Educação Ambiental.

Malacarne e Strieder (2009) chamam a atenção dos gestores públicos, para o caso do ensino de Ciências e das questões ambientais suscitadas por essa disciplina. Os professores das séries iniciais, normalmente têm pouca ou nenhuma formação específica em ciências, que respalde sua presença nesta disciplina. Tal formação deficiente tende a acarretar insegurança no docente, em sua prática profissional, quando aborda temáticas nesta dimensão, gerando uma dependência nociva do livro didático. Este, em muitos casos, contendo conteúdos desvinculados do cotidiano e do contexto dos alunos.

Sobre a importância da implementação da temática educação ambiental, dos docentes entrevistados 100,0\% considerou importante a implantação da temática ambiental na grade curricular.

Em atendimento ao segundo objetivo específico que busca Identificar as estratégias utilizadas pelos professores para a compreensão e entendimento dos alunos da temática Educação Ambiental detalhará sobre as Representações Sociais eliciadas pelos sujeitos relativamente a questão: "na sua percepção, o que representa a Educação Ambiental?”. Neste caso, três categorias se sobressaíram, a saber:

Categoria 1: Cidadania. Esta categoria parece associada a um incentivo a participação ativa individual e coletiva, permanente e responsável na preservação do equilíbrio ambiental. Representou $16,7 \%$ das falas.

Categoria 2: Sustentabilidade. Nesta categoria os sujeitos eliciaram representações centradas nas condições concretas para a existência da vida. Também associada às questões de saúde e de uma sobrevivência sadia. Representou 37,8\% das falas.

Categoria 3: Educação e Responsabilidade. Esta categoria eliciou frases que sugeriram uma associação entre a Educação Ambiental como um processo educativo intencional, que traz uma compreensão mais profunda e um aprendizado ético. Representou 45,5\% das falas. 
Id on Line Revista Multidisciplinar e de Psicoloqia

Id on Line Multidisciplinary Journal and Psycology

A tabela a seguir, apresenta as falas e suas respectivas frequências sobre as representações sociais de Educação Ambiental pelos sujeitos da amostra. Escola Dionísio Bom de Oliveira e Escola Moisés bom de Oliveira, no ano 2014.

\begin{tabular}{|c|c|c|}
\hline CATEGORIA & $\mathbf{F}$ & $\%$ \\
\hline $\begin{array}{l}\text { CIDADANIA } \\
\text { “... preservação do meio ambiente...; ... agente importante na preservação...; } \\
\text {...atitudes conscientes...; ... cuidados com o meio ambiente... , ...comportamento } \\
\text { responsável ...; ... preservar o espaço em que vive...; ... é a maneira para nós } \\
\text { cuidarmos do meio ambiente..., ... estratégias no sentido da prática...; ... ações } \\
\text { que protejam o meio ambiente...; ... atitudes e percepção do ambiente em que } \\
\text { vivemos...; ... representa atitudes adequadas...; ... Postura adequada...;... } \\
\text { atitudes que contribuam...; ; conscientização da importância do meio ambiente } \\
\ldots, \text {....respeitar o meio ambiente”. }\end{array}$ & 15 & $16,7 \%$ \\
\hline $\begin{array}{l}\text { SUSTENTABILIDADE } \\
\text { “ ambiente e sua relação com a natureza... ; relação das pessoas com o } \\
\text { meio...,... ter um comportamento adequado no meio em que habita...; ... união } \\
\text { do homem com a natureza...; ... importância do meio ambiente (água, luz, solo } \\
\text { e ar) para a vida...; ...preservação...; ... envolve os seres vivos e as casas... ... } \\
\text { preservando o meio ambiente...; ... conviver com uma realidade modificada...; } \\
\text {...provocar menos impacto..... meio ambiente e todos os seres...; ... ambiente } \\
\text { ecologicamente correto...; ... coleta seletiva do lixo e reflorestamento...; ... as } \\
\text { plantas, os animais e as pessoas que habitam o plante terra...; ... dentro do } \\
\text { espaço em que vivemos...; ... forma correta de cuidar do meio ambiente....; } \\
\text {...melhoria na qualidade de vida; ...;... um ambiente limpo, saudável e } \\
\text { organizado...; ...pessoas aprendem a convivem...; ... cuidados que devemos ter } \\
\text { com o nosso planeta...; ... garantirmos o futuro das próximas geraçães ...; ... } \\
\text { cuidado com o nosso planeta...; ... temos que cuidar do meio ambiente...; ... } \\
\text { menos doenças...; ... vida saudável...; ... conservação do meio ambiente...; ... } \\
\text { sem agredir a fauna e a flora;... conscientização em relação aos impactos } \\
\text { ambientais...;...importância da preservação ambiental...; ...preservação dos } \\
\text { recursos naturais...;... mudança na sociedade...; ... um futuro melhor...; ... } \\
\text { trabalho coletivo...; mostra atitudes”. }\end{array}$ & 34 & $37,7 \%$ \\
\hline 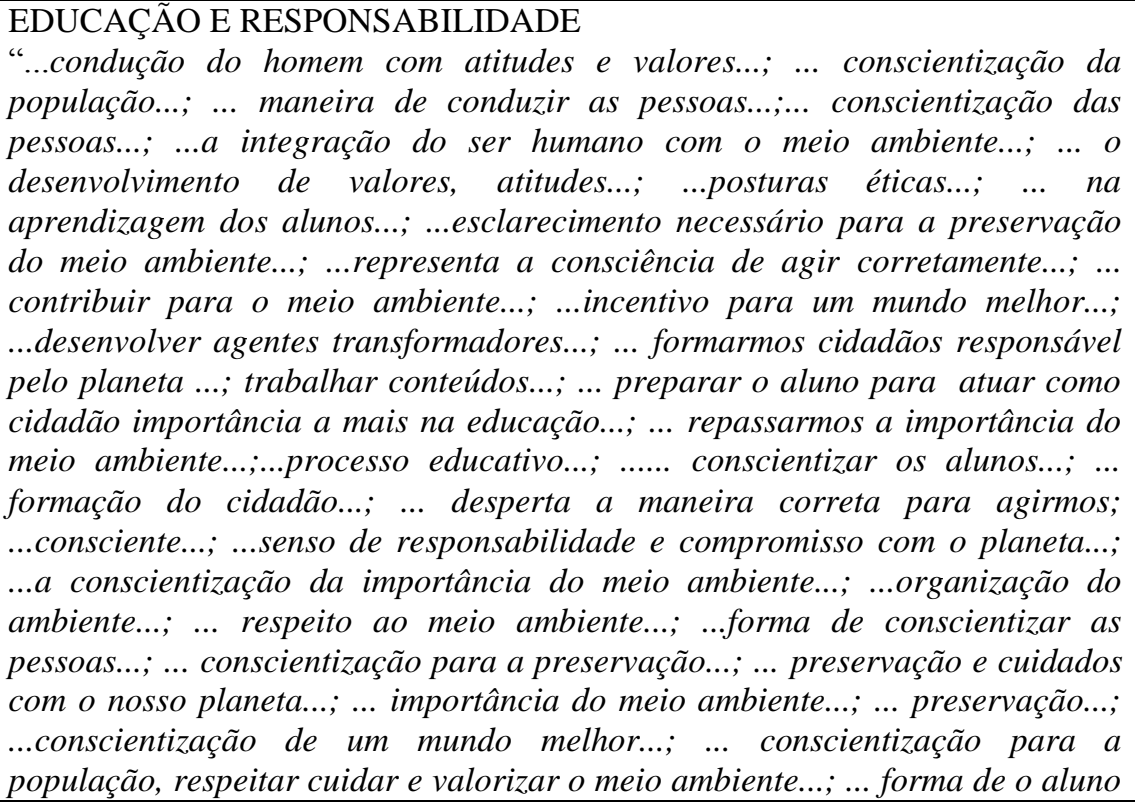 & 41 & $45,5 \%$ \\
\hline
\end{tabular}


Id on Line Revista Multidisciplinar e de Psicoloqia

Id on Line Multidisciplinary Journal and Psycology

\begin{tabular}{l|c|c|c}
\hline agir.....; ... consciente com o meio...senso de responsabilidade ; ... meio de & & \\
socializar e humanizar...; ...pratica consciente ... ; ...consciência de \\
indivíduos..
\end{tabular}

Tabela 10 - Representações sociais

Com relação a tabela acima, observa-se que houve uma maior associação de Educação Ambiental como educação e responsabilidade (45,5\%), o que parece insinuar noções de uma ética consciente, que envolve a consolidação de valores humanos como o respeito e a solidariedade para com o que é coletivo.

Observe-se que, uma providência da lei $\mathrm{n}^{\mathrm{o}}$ 9.795, que instituiu a Política Nacional de Educação Ambiental, foi associada ao caráter educacional. Nesse sentido, a educação ambiental é tida como um componente essencial e permanente da educação nacional. É preciso, pois, que esteja presente, de forma articulada, em todos os níveis e modalidades do processo educativo (BRASIL, 1999).

No ensino formal, a educação ambiental é entendida como aquela desenvolvida na sala de aula, por imposição curricular nas instituições de ensino públicas e privadas. A ideia é fortalecer ações e práticas educativas que estejam mais voltadas à sensibilização da coletividade, com relação às questões ambientais e à organização de ações que fortaleçam a organização e participação comunitária na defesa da qualidade do meio ambiente.

Não menos significativo foram as representações sociais associadas a sustentabilidade $(37,8 \%)$, onde os sujeitos demonstraram uma preocupação para com ações que promovam a vida saudável no planeta. Neste sentido, as respostas estão de acordo com o discurso de Dias (2004), que enfoca o meio ambiente como não apenas formado por flora e fauna, solo, água e ar, como é tradicionalmente definido. Mas que, é necessário considerar também aspectos políticos, econômicos, éticos, sociais e ecológicos, numa visão mais global do problema e das alternativas de soluções.

As representações sociais de Educação Ambiental também estiveram associadas a cidadania $(16,7 \%)$, isto é, denotaram um sentimento de responsabilidade, com participação mais ativa dos indivíduos para a preservação do equilíbrio ambiental. A educação tem a capacidade de promover valores, não sendo somente um meio de transmitir informações, trata-se de um processo que envolve transformações no sujeito que aprende e incide sobre sua identidade e posturas diante do mundo.

Neste caso, estando de acordo com a Política Nacional de Educação Ambiental, que tem como um de seus objetivos fundamentais, o senso de fortalecimento da cidadania, através do incentivo à participação individual e coletiva, de forma permanente e responsável, que levem a preservação do 
Id on Line Revista Multidisciplinar e de Psicoloqia

Id on Line Multidisciplinary Journal and Psycology

equilíbrio do meio ambiente, entendendo o meio ambiente como um valor inseparável do exercício da cidadania (BRASIL, 1999).

Sobre a prática que os professores utilizam para desenvolver EA no ambiente educacional atendendo ainda sobre o segundo objetivo específico onde busca discutir a prática que os professores utilizam para desenvolver Educação ambiental no ambiente educacional, fez necessário elencar os Projetos ambientais desenvolvidos nas escolas.

\begin{tabular}{lcc}
\hline Projetos Ambientais desenvolvidos & Frequência & Percentual (\%) \\
\hline Horta de jardinagem & 27 & 67,5 \\
\hline Palestras de conscientização & 08 & 20,0 \\
\hline Reciclagem & 04 & 10,0 \\
\hline Visitas & 01 & 2,5 \\
\hline Total & & $\mathbf{1 0 0 , 0}$ \\
\hline
\end{tabular}

Tabela 11 - Projetos Ambientais desenvolvidos pelos Professores

Dos $71,1 \%$ dos professores que afirmaram implementarem Projetos ambientais na sua escola ( informação da tabela 9), 67,5\% trabalha com Horta e jardinagem; 20,0\% facilita Palestras de conscientização; $10,0 \%$ trabalha e estimula a reciclagem e, $2,5 \%$ trabalha com visitação.

Quando se trata de desenvolvimento de projetos ambientais no âmbito escolar, Schon (1995) destaca a importância desta reflexão na ação docente. $\mathrm{O}$ autor entende que, tal reflexão na ação ajuda na formação do pesquisador no contexto prático. No mundo real prático, os problemas não são apresentados como dados, que devem ser construídos, partindo-se de elementos das situações problemáticas, inquietantes e incertas.

Para isso, é importante apropriar-se da metodologia científica para converter uma situação problemática num problema. Elliot (1994) acredita que deve refletir-se sobre uma situação ambígua, não bem compreendida e, na escola, todos participarem da investigação educativa em sala de aula, como sujeitos ativos nesse processo. Os problemas devem ser reais, concretos, e que apresentem dificuldades cotidianas, de forma a constituírem-se em objeto de investigação. È necessário destacar que estamos nos referindo-nos a professores e alunos reais, como sujeitos sociais que, dialeticamente, tanto implicam como são implicados no contexto educacional e socioambiental.

A pesquisa-ensino, como modalidade específica propõe uma análise crítica da realidade social e escolar, movida por uma visão dialético-reflexiva, em busca de uma transformação. Isso se justifica em René Barbier (2002), quando cita que a pesquisa-ação tem uma preocupação deliberada de transformar a realidade. Constituindo-se num tipo de pesquisa com um duplo objetivo: a) transformar a realidade e, b) produzir conhecimentos associados a essas transformações. 
Id on Line Revista Multidisciplinar e de Psicoloqia

Id on Line Multidisciplinary Journal and Psycology

Questionamos se na escola existe o processo de separação de lixo produzido pela comunidade escolar. Os resultados na Tabela 12. É importante que sejam providenciadas a coleta seletiva (visa em separar e classificar o lixo para que se possam aproveitar tudo o que é reciclável). Nesse processo é preciso separar o material inorgânico - vidro, papel, metais, plásticos, papéis; do orgânico - composto de restos de comida, frutas, verduras, aparas de grama e esterco de animais, em recipientes de cores diferenciadas.

\begin{tabular}{lcc}
\hline A escola possui separação do lixo? & frequência & Percentual $(\boldsymbol{\%})$ \\
\hline Sim & 03 & 6,7 \\
\hline Não & 41 & 91,1 \\
\hline Não Respondeu & 01 & 2,2 \\
\hline Total & $\mathbf{4 5}$ & $\mathbf{1 0 0 , 0}$ \\
\hline
\end{tabular}

Tabela 12 - Separação do lixo

A coleta seletiva exige um exercício de cidadania, no qual os cidadãos assumem um papel ativo em relação à administração da cidade. Além das possibilidades de aproximação entre a população e o poder público, a coleta seletiva pode estimular a organização da sociedade civil.

Na Tabela 13, os resultados sobre : Os professores realizam atividades com os alunos fora da escola para trabalhar a realidade local sobre as questões ambientais?

\begin{tabular}{l|c|c}
\hline $\begin{array}{l}\text { Professores realizam atividades fora da } \\
\text { escola sobre as questões ambientais locais? }\end{array}$ & frequência & Percentual (\%) \\
\hline Sim & 19 & 42,2 \\
\hline Não & 26 & 57,8 \\
\hline Total & $\mathbf{4 5}$ & $\mathbf{1 0 0 , 0}$ \\
\hline $\begin{array}{l}\text { Com que frequência realizam atividades } \\
\text { fora da escola sobre as questões ambientais } \\
\text { locais? }\end{array}$ & Frequência & Percentual (\%) \\
\hline Nunca & 15 & 33,3 \\
\hline Raramente & 18 & 40,0 \\
\hline Frequentemente & 1 & 2,2 \\
\hline Sempre & 1 & 2,2 \\
\hline Não respondeu & 10 & 22,2 \\
\hline Total & $\mathbf{4 5}$ & $\mathbf{1 0 0 , 0}$ \\
\hline
\end{tabular}

Tabela 13 - Atividades para trabalhar EA 
Id on Line Revista Multidisciplinar e de Psicoloqia

Id on Line Multidisciplinary Journal and Psycology

Como assinala Freire (1987), o educador ao ligar o conteúdo das ciências às questões do cotidiano torna a aprendizagem mais significativa. É através de um ensino investigativo, provocativo que o aluno começa a pensar e a refletir sobre o processo de construção do conhecimento.

Segundo Segura (2001, p. 71): "A ênfase em atividades práticas talvez seja um reflexo da própria rotina atribulada das escolas: muitas aulas, muitos alunos, carência material e sobrecarga burocrática". A educação ambiental é um conjunto de práticas e conceitos voltados para a busca da qualidade de vida, com o objetivo de criar diretrizes para autossustentabilidade da região.

Buscou-se identificar as contribuições dos professores para a formação de alunos agente multiplicadores no âmbito ambiental.

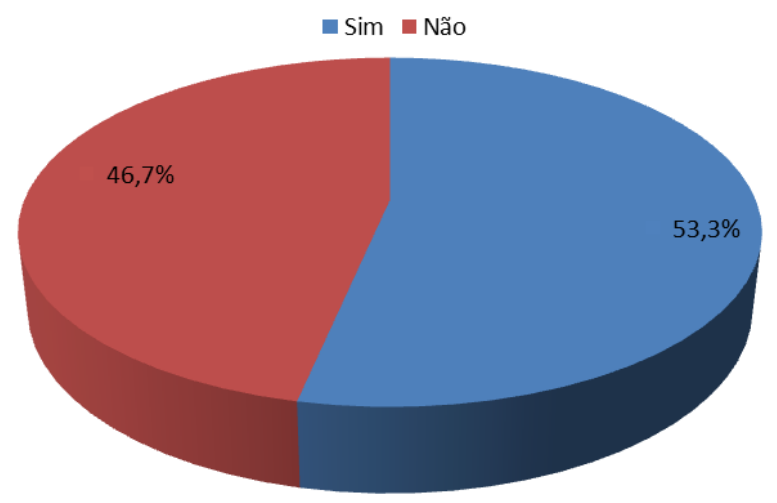

Gráfico 2 - Possibilidade de mudar de emprego

Assim, questionamos sobre a atuação do professor. Indagados se gostam da profissão de professor, todos foram unânimes em dizer que sim, que gostam de atuar como educadores. Porém, quando indagados sobre a possibilidade de mudar de profissão, 24 professores disseram que sim $(53,3 \%)$, enquanto 21 professores disseram que não o fariam $(46,7 \%)$. Observe-se que, apesar de serem unânimes em afirmar que gostam da profissão de professores, 53,3\% nos revelou que, se pudesse, mudaria de profissão. O que nos parece uma ambiguidade.

É possível que, com a limitação na formação ou, com a pouca ou nenhuma educação continuada, o conhecimento científico mais específico, que compreendem o ambiente possam funcionar como fatores desestimulantes aos professores. Também a falta de apoio, espaço e recursos materiais para levarem a cabo projetos mais ousados e interessantes, sejam um dificultador na motivação dos mesmos para continuarem na profissão.

Os professores, devido a sua posição de líderes podem contribuir com o aprendizado sobre o meio ambiente despertando no alunado o gosto e a paixão pela natureza, assim se consegue desenvolver as habilidades de observar, analisar, comparar, criticar, criar, recriar e elaborar. Além 
Id on Line Revista Multidisciplinar e de Psicoloqia

Id on Line Multidisciplinary Journal and Psycology

disso, a realização conjunta das atividades em diferentes áreas de estudo ou disciplinas e do esforço coletivo do corpo dirigente, do corpo docente e corpo discente associado à família e à comunidade resultará em um trabalho interdisciplinar para o desenvolvimento da Educação Ambiental na escola. A Educação Ambiental assim compreendida é uma alternativa de ensino que oferece, à escola, uma grande chance de renovação.

Em atendimento ao terceiro objetivo específico, Identificar as contribuições dos professores para a formação de alunos agente multiplicadores no âmbito ambiental, apresentamos as contribuições que os sujeitos esperam com a implantação da temática Educação Ambiental.

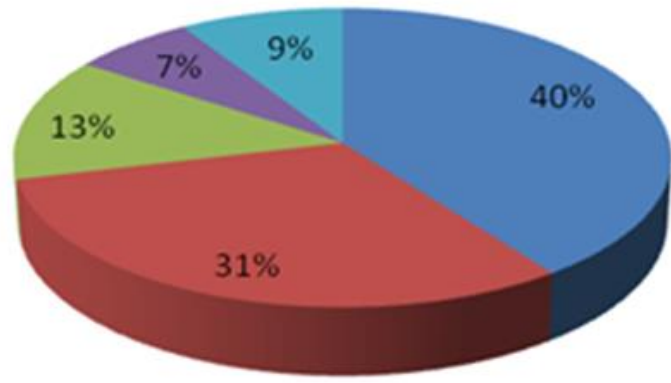

\author{
- Conscientizar sobre \\ importância de preservar \\ : Promover aprendizado \\ sobre como preservar \\ - Oferecer condições para \\ um posicionamento mais \\ critico \\ - Desenvolver novos \\ hábitos mais sustentáveis
}

não responderam

\title{
Gráfico 3 - Contribuição da EA
}

As respostas foram organizadas conforme os seguintes tópicos: Conscientizar sobre a importância de se preservar o meio ambiente de maneira responsável - 18 respostas (40\%); Promover um aprendizado sobre como preservar para melhorar a qualidade de vida no planeta - 14 respostas $(31,1 \%)$; Oferecer condições para um posicionamento mais crítico e reflexivo sobre as ações do homem e suas consequências na natureza 6 respostas (13,3\%); Desenvolver novos hábitos mais sustentáveis, capazes de mudar a realidade atual- 3 respostas $(6,7 \%)$. Não responderam a esta questão -4 sujeitos $(8,9 \%)$

Para a EA vista como aposta de vida, prática cidadã e construção cotidiana de uma nova sociedade, este conceito parece mais "iluminado" de sentido pois estabelece uma série de outras conexões importantes: a relação eu-nós 
pressupõe envolvimento solidariedade e a própria participação. Poderia ter escolhida "conscientização" ou "sensibilização", talvez as expressões mais citadas quando se fala em EA, mais foi buscada no conceito de pertencimento uma síntese dessas duas ideias (SEGURA, 2001, p. 48).

Sobre a escola atingir aos objetivos interdisciplinares quanto a educação ambiental, as respostas estão dispostas no gráfico a seguir.

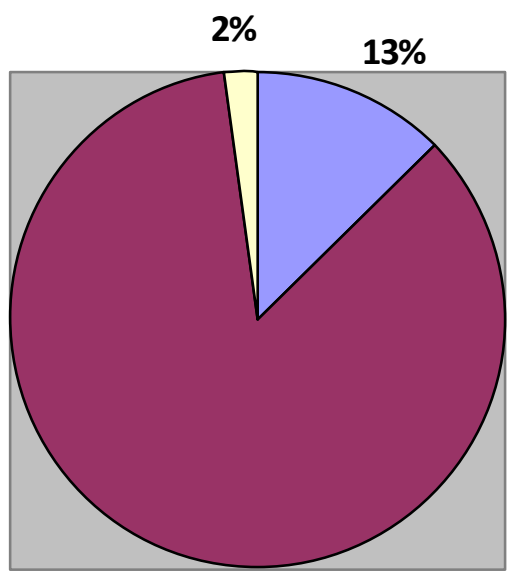

\begin{tabular}{|l|}
$\square$ Sim \\
$\square$ Não \\
$\square$ Não respondeu
\end{tabular}

$85 \%$

\section{Gráfico 4 - Objetivos interdisciplinares}

Conforme se observa no gráfico acima, $85 \%$ dos entrevistados afirmam que a escola não tem atingido os objetivos interdisciplinares quanto a educação ambiental, enquanto 13\% discordam afirmando o contrário, que tal contribuição existe; $2 \%$ não respondeu à pergunta. A educação ambiental escolar deve enfatizar o estudo do meio ambiente onde vive o aluno, procurando levantar os principais problemas da comunidade, quais as contribuições da ciência e os conhecimentos necessários, assim como as possibilidades concretas para a solução deles. Segundo Segura (2001):

A escola foi um dos primeiros espaços a absorver esse processo de "ambientalização" da sociedade, recebendo a sua cota de responsabilidade para melhorar a qualidade de vida da população, por meio de informação e conscientização (SEGURA, 2001, p. 21).

Para conscientizar um grupo, primeiro é preciso delimitar o que se quer e o que deseja alcançar. Para que o interesse desperte no aluno, é necessário que o professor utilize a "bagagem de 
Id on Line Revista Multidisciplinar e de Psicoloqia

Id on Line Multidisciplinary Journal and Psycology

conhecimentos trazidos de casa" pelos alunos, como dizia Freire (1987), assim levando-o a perceber que o problema ambiental esta mais perto de todos, do que se imagina.

Freire (2005, p. 82), explica que "na prática problematizadora, vão os educandos desenvolvendo o seu poder de captação e de compreensão do mundo que lhes aparece, em suas relações com ele, não mais como uma realidade estática, mas como uma realidade em transformação, em processo". Para que a EA se efetive no ambiente escolar é necessário que professores e estudantes estabeleçam uma relação direta entre o conhecimento dos conteúdos "disciplinares" e os problemas vividos em sociedade e, principalmente, no ambiente em que vivem.

\section{Conclusões}

A investigação foi desenvolvida com a temática Educação Ambiental tendo como foco o diálogo entre a legislação e a prática dos professores sobre a Educação Ambiental em escolas públicas. O principal objetivo foi discutir como acontece esse diálogo, sendo os locais de pesquisa entre a legislação e a prática dos professores sobre a Educação Ambiental em duas escolas públicas de Araripina - Pernambuco entre 2013 e 2014: Dionísio Bom de Oliveira e Moisés Bom de Oliveira. O universo de pesquisa compreendeu 45 docentes.

Objetivo específico 1: Descrever como os professores conseguem integrar os alunos numa consciência coletiva conforme a Legislação.

Constatamos que a integração entre os alunos acontece principalmente no ambiente escolar, possuindo a escola área arborizada; com incentivos no desenvolvimento das atividades ambientais com os alunos, com desenvolvimento de projetos ambientais; com uso de livros didáticos que trazem conteúdos acerca da temática.

Observou-se que a estratégia mais utilizada para integrar os alunos numa consciência coletiva conforme a Legislação foi a música, seguida do debate e do desenho. Outras estratégias, utilizadas em menor escala, porém utilizadas, são: vídeo e as brincadeiras; passeios e as palestras. Em escala ainda menor, também são utilizadas: o Teatro e os painéis educativos, a separação do lixo e as cartilhas. Os professores asseveram que existem dificuldades na implementação de atividades de educação ambiental, sendo essas: falta de apoio e recursos; disposição e conscientização por parte dos próprios educadores; o espaço e o tempo para implementação das atividades; a falta de material didático atualizado.

Objetivo especifico 2: Identificar as estratégias utilizadas pelos professores para a compreensão e entendimento dos alunos da temática Educação Ambiental. 
Id on Line Revista Multidisciplinar e de Psicoloqia

Id on Line Multidisciplinary Journal and Psycology

Em primeiro termo os professores indicaram que a EA deve constar na grade curricular. Em segundo lugar, os professores tiveram oportunidade de colocar suas representações sociais, percepções e sentimentos. Em suas falas, a Educação Ambiental é componente essencial, principalmente quando diz respeito a uma educação de formação de valores humanos, despertando um maior interesse para o meio ambiente enquanto lugar de promoção de cidadania, da sustentabilidade, da educação e responsabilidade. Em terceiro lugar, os professores realizam com os seus alunos projetos de horta e jardinagem, palestras, trabalho, estímulo à reciclagem e visitação. Tudo se faz com uma frequência escassa.

Objetivo específico 3: Identificar as contribuições dos professores para a formação de alunos agente multiplicadores no âmbito ambiental.

Tendo em vista ser a Educação Ambiental uma importante abordagem dada as dificuldades por que passa o planeta, em suas diversas dimensões, mostram-se importantes para a construção deste conhecimento específico, através de reflexões e discussões de experiências e possíveis ações. Assim, as contribuições dos professores estão em: Promover um aprendizado sobre como preservar para melhorar a qualidade de vida no planeta; Oferecer condições para um posicionamento mais crítico e reflexivo sobre as ações do homem e suas consequências na natureza; Desenvolver novos hábitos mais sustentáveis, capazes de mudar a realidade atual.

Em relação ao objetivo específico, constatamos que a educação ambiental foi percebida pelos sujeitos da amostra, como um processo de educação e reflexão permanente, na construção de sujeitos cidadãos. No âmbito do ensino, suas ações e práticas educativas, deveriam estar voltadas à sensibilização da coletividade sobre as questões ambientais emergentes, bem como a sua organização e participação, na luta por uma melhor qualidade do meio ambiente. As propostas (estratégias e atividades) utilizadas pelos professores na implementação da Educação Ambiental, ainda que, com dificuldades, propõe o repensar da prática por meio da teoria, com a transformação das relações de sociais que determinam a problemática ambiental na sociedade atual, e determina a organização do trabalho didático na escola pública, tornando viável a inserção da educação ambiental no currículo escolar.

Concluímos que o diálogo entre teoria e prática nas escolas investigadas necessita de maior efetividade para minimizar as dificuldades para implementação e estímulo a atividades e projetos de Educação Ambiental. Isso implica em disponibilizar material didático adequado e em quantidade suficiente, melhorar a estrutura física das escolas, financiar capacitação dos educadores na temática, bem como organizar na grade curricular, um tempo para que os professores tenham disponibilidade para atividades desta natureza. A possibilidade de atuar com práticas ambientais mais efetivamente, 
Id on Line Revista Multidisciplinar e de Psicoloqia

Id on Line Multidisciplinary Journal and Psycology

ampliaria a autonomia de professores e alunos, numa ação social que beneficiaria tanto a escola como a própria comunidade e o ambiente no qual ela se insere.

\section{Recomendações}

Diante dos resultados e alcance dos objetivos propostos no início de nossa investigação, percebemos a necessidade de conceber a formação continuada do professor quanto à Educação Ambiental, por meio de um método que lhe possibilite o exercício de seu trabalho docente com total autonomia e domínio do conhecimento, pois, é ainda desafiador para eles que estão comprometidos com a educação ambiental crítica, o aprofundamento e maior desenvolvimento de estratégias e atividades práticas acerca desse tema.

Recomenda-se a articulação de ações educativas, oferta de condições adequadas e capacitações aos professores para que possam trabalhar temas e atividades de Educação Ambiental, de maneira que possibilite a conscientização dos alunos e desenvolva a criticidade dos mesmos, gerando novos conceitos e valores sobre a natureza, contribuindo para a preservação do meio ambiente.

\section{Referências}

BARDIN, L. Análise de conteúdo. Lisboa: Edições 70, 1977.

BARROS, Aidil de Jesus Paes de. LEHFELD, Neide Aparecida de Souza. Projeto de Pesquisa: propostas metodológicas. $13^{\mathrm{a}}$ ed. Petrópolis, RJ: Vozes, 2002. 128p. ISBN 85.326.0018-2.

BERNA, Vilmar. Como fazer educação ambiental. 2. ed. São Paulo: Paulus, 2004.

BISPO, M. O.; OLIVEIRA, S. F. Diferentes olhares sobre o Meio Ambiente e Educação Ambiental: as representações dos professores de Cristalândia - TO.. Revista Eletrônica do Mestrado em Educação Ambiental. v 18, p. 399-414, jan/jun. 2007.

BRASIL. Constituição da República Federativa do Brasil. Brasília: Senado, 1988.

LDB: Lei de diretrizes e Bases da Educação Nacional. Lei n 9.394 , de 20 de dezembro de 1996, 9ª ed. - Brasília: Câmara dos Deputados, 2014.45 p

Política Nacional de Educação Ambiental. Lei n. ${ }^{\circ}$ 9.795, 27 de abril de 1999. Disponível em http://www.planalto.gov.br/ccivil_03/leis/19795.htm. Acesso em: 16 jan. 2013.

Política Nacional do Meio Ambiente. Lei n. ${ }^{\circ} 6.938$ de 31 de agosto de 1981. Disponível em http://www.planalto.gov.br/ccivil_03/leis/16938.htm. Acessado em 15 de janeiro de 2013. 
Id on Line Revista Multidisciplinar e de Psicologia

Id on Line Multidisciplinary Journal and Psycology

Secretaria de Educação Ambiental. Parâmetros Curriculares Nacionais. São Carlos - SP. Dissertação (mestrado em Educação) - Universidade Federal de São Carlos, São Carlos, 2003.

BRASIL ESCOLA. Educação Ambiental na Formação de Professores. Quem se Importa? Disponível em: <http://monografias.brasilescola.com/educacao/educacao-ambiental-na-formacaoprofessores.htm>. Acesso em: 20 out. 2013.

BRÜGGER, P. Educação ou adestramento ambiental? 2. ed. Florianópolis: Letras Contemporâneas, 1999.

BUSQUETS, M. D. Temas transversais em educação: bases para uma formação integral. Trad. Cláudia Schilling. São Paulo: Ática, 2000.

CARVALHO, L. M. A. A temática ambiental e o processo educativo: dimensões e abordagens. In:

CINQUETTI, H. S.; LOGAREZZI, A. Consumo e resíduos - Fundamentos para o trabalho educativo. São Carlos: EdUFSCar, 2006.

CARVAlHO, Vilson Sérgio de. A Educação Ambiental nos PCN's: o meio ambiente como tema transversal. Rio de Janeiro: MZ Editora, 2000.

CASCINO, F. Educação ambiental: princípios, história, formação de professores. $4^{\circ}$ ed. São Paulo: Ed. Senac, 2007.

CHACON. Justo Penteado. S.O.S. Meio Ambiente. Revista Mundo Jovem. Sorocaba - SP, 2014.

CRESWELL, John W. Projeto de pesquisa: métodos qualitativo, qualitativos e mistos. 3. ed. Porto Alegre: Artmed, 2010.

CUNHA, A. M. O.; KRASILCHIK, M. A formação continuada de professores de ciências: percepções a partir de uma experiência. In: Reunião da Associação Nacional de Pós-Graduação d Pesquisa em Educação, 23. Caxambú. Anais... Caxambú: ANPED, 2000. p. 1-14.

DIAS, Genebaldo Freire. Educação Ambiental: Princípios e Práticas. $9^{\circ}$ ed. São Paulo: Gaia, 2004.

Educação ambiental: princípios e práticas. 8. ed. São Paulo: Gaia, 2003.

Educação Ambiental: princípios e práticas. 5ª ed. São Paulo: Gaia, 1998.

Atividades interdisciplinares de educação ambiental. São Paulo: Global/Gaia.1994.

Educação, Geografia e o desafio de novas tecnologias. Rev. Port. De Educação. vol. 24 no. 2. Braga, 2011. Disponível em: <http://www.scielo.oces.mctes.pt/scielo.php?pid=S087191872011000200010\&script=sci_arttext $>$. Acesso em: 20 out. 2013.

ESCOLA MOISÉS BOM DE OLIVEIRA. Projeto político pedagógico, 44p. Secretaria de Educação do Estado de Pernambuco, Araripina - PE, 2013

Eventos UNIC Rio - 22 jun. 2012. Compromissos Voluntários para o Desenvolvimento Sustentável são anunciados na Rio+20. Disponível em: <http://www.unicrio.org.br/705compromissos-voluntarios-para-o-desenvolvimento-sustentavel-sao-anunciados-na-rio20/>. Acessado em 25 abr. 2013 
Id on Line Revista Multidisciplinar e de Psicologia

Id on Line Multidisciplinary Journal and Psycology

FARIAS, José Mauro. Educação Ambiental na Formação de Professores. Quem se Importa? Disponível educacao-ambiental-na-formacao-professores.htm. Acessado em: 20 de Outubro de 2013

FREIRE, Paulo. Pedagogia da Autonomia: Saberes necessários à prática educativa. $7^{\mathrm{a}}$ edição. São Paulo: Paz e Terra, 1996.

GOUVÊA, G. R. R. Rumos da formação de professores para a Educação Ambiental Educar, Curitiba, n. 27, p. 163-179, 2006. Editora UFPR.

GUERRA, A. F. S.; GUIMARÃES, M. Educação Ambiental no Contexto Escolar: questões levantadas no GDP. Pesquisa em Educação Ambiental. vol. 2, nº 1, p. 155- 1666. 2007.

GUIMARÃES, M. A dimensão ambiental na educação. Campinas: Papirus, 1995.

GIL, A.C. Métodos e técnicas de pesquisa social. 5 ed. São Paulo: Atlas, 1999.

KENSKI, V. M. O papel do professor na sociedade digital. In: A. D. Castro; A. M. P. Carvalho (Org.). Ensinar a ensinar: Didática para a Escola Fundamental e Média. São Paulo: Ed. Pioneira Thomson Learning, 2002.

LEFF, E. Epistemologia ambiental. São Paulo: Cortez, 2001.

LERIPIO, Denize Longaray; SELIG, Paulo Maurício Selig. Educação Ambiental e Cidadania: a abordagem dos temas transversais. Núcleo de Gestão para Sustentabilidade, USFC. Disponível em: <http://ngs.ufsc.br/artigos/artigo.pdf>. Acessado em: 16 fev. 2013.

LIBÂNEO, José Carlos. Didática. São Paulo: Ed. Cortez, 1994.

MEGLHIORATTI, F. A.; BORTOLOZZI, J.; CALDEIRA, A. M. A. Educação, conteúdo disciplinar e atitude crítica na formação de professores. Revista Científica Eletrônica de Pedagogia, Garça, n. 5, jan. 2005.

MINAYO, M. C. S. O desafio de conhecimento: pesquisa qualitativa em saúde. 7. ed. São Paulo; Rio de Janeiro: Hucitec-Abrasco, 2000.

MINISTÉRIO DA EDUCAÇÃO. Secretaria da Educação Fundamental. Parâmetros Curriculares Nacionais - Meio Ambiente e Saúde. Brasília: MEC, 2001.

MINISTÉRIO DO MEIO AMBIENTE (MMA). Agenda 21. Disponível em: www.mma.gov.br/sitio/index. php?ido=conteudo.monta\&idEstrutura=18. Acesso em: 04 de fevereiro de 2013.

MORIN, Edgar. Os sete saberes necessários à educação do futuro. 11. ed. São Paulo: Cortez, 2006.

OLIVEIRA, Haydée Torres de. Educação ambiental - ser ou não ser uma disciplina: essa é a principal questão?! In: Vamos cuidar do Brasil: conceitos e práticas em educação ambiental na escola. Ministério da Educação/MEC. Departamento de Educação Ambiental. Brasília, 2007.

Parâmetros para a Educação Básica do Estado de Pernambuco. Secretaria de Educação de Pernambuco. Disponível em: <http://www.educacao.pe.gov.br/portal/?pag=1\&cat=36\&art=1047>. . Acessado em: 19 ago. 2013. 
Id on Line Revista Multidisciplinar e de Psicologia

Id on Line Multidisciplinary Journal and Psycology

PENTEADO, H. D. Meio ambiente e formação de professores. 6. ed. São Paulo: Cortez, 2007.

PÉREZ GOMEZ, A. I. A função e formação do professor/a no ensino para a compreensão: diferentes perspectivas. In: SACRISTÁN, J. G.; PÉREZ GOMEZ, A. I. Compreender e transformar o ensino. Trad. Ernani F. da Fonseca Rosa. 4 ed, Artmed. Porto Alegre, 1998.

PREFEITURA MUNICIPAL DE ARARIPINA. Araripina, Lei Orgânica do Município de 05 de abril de 1990. Revisado em 2010.

SANTOS, José Messias dos; PEREIRA, Adilson. Cosmovisão, epistemologia e educação: uma compreensão holística da realidade. 2 ed. Rio de Janeiro: Editora Gama Filho, 1999.

SEGURA, Denise de S. Baena. Educação Ambiental na escola pública: da curiosidade ingênua à consciência crítica. São Paulo: Annablume: Fapesp, 2001.

SOARES et.al. Saúde e qualidade de vida do ser humano no contexto da interdisciplinaridade da Educação Ambiental. No. $38-05$ de. 2011. Disponível em: <http://www.revistaea.org/artigo.php?idartigo=1143>. Acesso em: 09 abr. 2012.

SORRENTINO, M. De Tbilisi a Tessaloniki, a educação ambiental no Brasil. In: JACOBI, P. et. al. (orgs.). Educação, meio ambiente e cidadania: reflexões e experiências. São Paulo: SMA, 1998. p. 27-32.

SPINK, M. J. Desenvolvendo as teorias implícitas: uma metodologia de análise das representações sociais. In: GUARESCHI, P. A.; JOVCHELOVITCH, S. (Orgs.). Textos em representações sociais. 7. ed. Petrópolis: Vozes, 2002. p. 117-145.

. O conceito de representação social na abordagem psicossocial. Cadernos de Saúde Pública, Rio de Janeiro, n. 9, v. 3, p. 300-308, 1993.

TARDIF, M. Saberes docentes e formação profissional. Petrópolis: Vozes, 2002.

TÉBAR, Lorenzo. O perfil do professor mediador: Pedagogia da Mediação. Tradução de Priscila Pereira Mota. São Paulo: Editora Senac, 2011.

TOMAZELLO, M. G. C. Educação Ambiental: a abordagem pedagógica de trabalho por projeto. Revista Eletrônica do Mestrado de Educação Ambiental, v. 5, p. 1-6, jan/fev/mar. Fundação Universidade Federal do Rio Grande. Rio Grande-RS, 2001.

WIKIPEDIA. Araripina. Disponível em: <pt.wikipedia.org/wiki/Araripina>. Acesso em: 15 maio 2013.

ZAKRZEVSKI, S.B.B; SATO, M. Refletindo sobre a formação de professores em educação ambiental. In: A contribuição da Educação Ambiental à Esperança de Pandora. SANTOS, J.E; SATO, M. São Carlos: RiMa, 2006. 
Id on Line Revista Multidisciplinar e de Psicoloqia

Id on Line Multidisciplinary Journal and Psycology

\section{Como citar este artigo (Formato ABNT):}

NASCIMENTO, M.C.D.; ROLON, J.C.C. Educação Ambiental: Um diálogo entre a Legislação e a Prática dos professores de Escolas Públicas de Araripina - PE, 2013-2014. Id on Line Revista Multidisciplinar e de Psicologia, Julho de 2016, vol.10, n.30, Supl 3, p. 143-177. ISSN 1981-1179.

Recebido: 20/05/2016

Aceito: 25/05/2016 